\title{
Variations of soil phosphatase activity and phosphorus fractions in ginger fields exposed to different years of chloropicrin fumigation
}

\author{
Yan Wang ${ }^{1,2} \cdot$ Xiaomei Yang ${ }^{1,3} \cdot{\text { Minggang X } \mathbf{X}^{2} \cdot \text { Violette Geissen }}^{1}$
}

Received: 8 September 2021 / Accepted: 1 January 2022 / Published online: 11 February 2022

(c) The Author(s) 2022

\begin{abstract}
Purpose Although soil fumigation efficiently controls soil-borne diseases, the effects of repeated soil fumigation on soil phosphorus (P) cycling are still largely unknown.

Methods In this study we conducted a field experiment to explore soil phosphorus availability in ginger fields with 0,3 , and 7 years (F0, F3, and F7) of annual chloropicrin (CP) fumigation history in Shandong Province of China. Soil samples $(0-20 \mathrm{~cm})$ were collected at four different times in 2019. Ginger yield, soil phosphatase (acid and alkaline) activities, and soil P fractions were measured.

Results Results showed that ginger rhizome yield was similar in F0 and F3 (70.0 t ha ${ }^{-1}$ ), but significantly lower in F7 $\left(37.5 \mathrm{t} \mathrm{ha}^{-1}\right)$. The acid phosphatase (AiP) activity was significantly higher in F0, while alkaline phosphatase (AlP) activity was the highest in F3. There was no significant difference in the available $\mathrm{P}$ (resin- $\mathrm{P}+\mathrm{NaHCO}_{3}-\mathrm{P}+\mathrm{NaOH}-\mathrm{P}$ ) between F0 and F7, with 33.6 to $57.5 \%$ of total P (TP), while the available $\mathrm{P}$ was significantly lower in F3, being less than $30 \%$ of TP. Redundancy analysis (RDA) showed that the highest $\mathrm{pH}$ values in $\mathrm{F} 3$ contributed to the lowest soil $\mathrm{P}$ availability there. AiP activities showed highly positive effects on the soil labile $\mathrm{P}$ contents.

Conclusion Results suggested that more P fertilizers are needed after 3 years of CP fumigation to avoid soil P deficiency for ginger growth. The death of ginger became the main limitation for ginger production after 7 years of CP fumigation, at which time, comprehensive agricultural practices should be considered to control ginger soil-borne diseases.
\end{abstract}

Keywords Fumigation $\cdot$ Chloropicrin $\cdot$ Ginger $\cdot$ Phosphatase activity $\cdot$ Soil $\mathrm{P}$ fractions

\section{Introduction}

Ginger (Zingiber offinale Rosc.) is an important commercial crop in China with high agricultural and medical value (Zhang et al. 2017a, b). During cultivation, ginger is prone

Responsible editor: Caixian Tang

Minggang Xu

xuminggang@caas.cn

1 Soil Physics and Land Management Group, Wageningen University, P.O. Box 47, 6700 AA Wageningen, The Netherlands

2 National Engineering Laboratory for Improving Quality of Arable Land, Institute of Agricultural Resources and Regional Planning, Chinese Academy of Agricultural Sciences, Beijing 100081, China

3 College of Natural Resources and Environment, Northwest A\&F University, Yangling 712100, Shaanxi, China to soft rot, bacterial wilt, leaf spot, and yellowing caused by soil-borne pathogens such as Pythium, Pseudomonas solaracearum, Ralstonia solanacearum, Phyllisticta, and Fusarium (Jiang et al. 2018). Under appropriate environmental conditions, soil-borne pathogens can invade ginger roots and stem bases, causing ginger diseases and reducing production (Mansfield et al. 2012).

To prevent soil-borne diseases in ginger crops, soil fumigation has become a key step prior to ginger cultivation in China (Rokunuzzaman et al. 2016). Among the various fumigants, chloropicrin (trichloronitromethane, CP) is one of the most widely used compounds owing to its advantageously high inhibitory efficiency on soil-borne pathogens and low environmental residues (Sun et al. 2018). Within several days after application, $\mathrm{CP}$ is broken down into nitrogenous compounds via both chemical and microbial processes (Neilson et al. 2020). The degradation rates of $\mathrm{CP}$ can be influenced by the application rate, soil moisture, 
organic matter content, and other soil properties (Ashworth et al. 2018; Ashworth and Yates 2019). Soil microorganisms that can metabolize and use $\mathrm{CP}$ as a source of energy and nutrients are main players in CP biodegradation (Qin et al. 2016). CP has received increasing attention over the last few years due to its broad antimicrobial activities, environmental behaviors, and ecological effects on the soil microbiome, soil enzymes, and ultimately on nutrient cycling and soil health (Pecina et al. 2016; Li et al. 2017a, b; Huang et al. 2020a).

Previous studies have shown that soil microbial communities recovered relatively rapidly after soil fumigation (Dangi et al. 2014, 2015; Liu et al. 2015; Rokunuzzaman et al. 2016; Fang et al. 2018; Zhang et al. 2019). Zhang et al. $(2017 \mathrm{a}, \mathrm{b})$ found that after repeated application of soil fumigants, susceptible soil microbes could disappear while the proportion of those tolerant microbes could increase gradually and even eventually dominate the soil microbiome. They concluded that after 3 years of continuous chloropicrin fumigation, seven genera of Actinobacteria and one genus in Bacteroidetes disappeared while Saccharibacteria increased significantly. Dangi et al. (2017) also found that there were significant differences in soil microbial communities between untreated sites and sites exposed to 15 and 30 years of annual fumigation with methyl bromide. All of these long-term studies revealed that the changes in the soil microbiome after long-term repeated soil fumigation were irreversible. Scientists do not yet know how long it would take for the soil microbial community to recover from repeated fumigation if it can recover at all.

With the potential for the reduced activity of soil organisms after soil fumigation, one major question is how nutrient cycles in soil could be affected. Among the diverse nutrient cycling processes in soil, many researchers have explored the detrimental effects of $\mathrm{CP}$ on nitrogen $(\mathrm{N})$ cycling and concluded that soil nitrification processes could be inhibited by soil fumigation in various soil types ( $\mathrm{Li}$ et al. 2017a, b; Yan et al. 2017; Fang et al. 2018; Sun et al. 2018).

Soil phosphorus $(\mathrm{P})$ is the second most important plant growth-limiting nutrient after nitrogen Although the soil system is rich in P, 95-99\% of the soil total P is present in an insoluble form (Wan et al. 2020) due to binding to the inorganic minerals or organic matter (Schaller et al. 2019), causing about $43 \%$ of the soils to be deficient in phosphorus available for plant growth (Zhao et al. 2019). On the other hand, phosphate rock as a raw material for phosphate fertilizer is a limited resource, which also emphasizes the urgent need to improve the availability of soil phosphorus for plant growth (Lemming et al. 2019). The soil $\mathrm{P}$ availability for plant uptake depends on the composition of different forms of $\mathrm{P}$ existing in the soil. Hedley's sequential extraction method (Hedley et al. 1982) for $\mathrm{P}$, based on the $\mathrm{P}$ availability for plants, classifies soil
$\mathrm{P}$ fractions as (1) resin- $\mathrm{P}$ (easily available $\mathrm{P}$ ), a soluble inorganic orthophosphate $\left(\mathrm{H}_{2} \mathrm{PO}_{4}{ }^{2-}\right.$ or $\left.\mathrm{H}_{2} \mathrm{PO}_{4}{ }^{-}\right)$in the soil solution and the only form that can be taken up by plants directly (Wang et al. 2012); (2) $\mathrm{NaHCO}_{3}-\mathrm{P}\left(\mathrm{NaHCO}_{3}-\mathrm{Pi}\right.$ and $\mathrm{NaHCO}_{3}-\mathrm{Po}$, labile $\mathrm{P}$ ), inorganic $\mathrm{P}$ fractions slightly complexed with $\mathrm{Fe} / \mathrm{Al}$ minerals and labile organic $\mathrm{P}$ fractions complex with organic matter surfaces; (3) NaOH-P (NaOH-Pi and NaOH-Po, moderately labile $\mathrm{P}$ ), $\mathrm{P}$ fractions strongly complexed with $\mathrm{Fe} / \mathrm{Al}$ minerals and calcic compounds, as well as organic $\mathrm{P}$ fractions more strongly associated with soil organic matter; and (4) occluded P (unavailable $\mathrm{P}$ ), which is occluded by soil aggregate and cannot be used by plants (Motavalli and Miles 2002; Koch et al. 2018; Fan et al. 2019). Among these soil P fractions, inorganic $\mathrm{P}$ fractions $\left(\mathrm{NaHCO}_{3}-\mathrm{Pi}\right.$ and $\left.\mathrm{NaOH}-\mathrm{Pi}\right)$ are available for plants after solubilization, while organic $\mathrm{P}$ fractions $\left(\mathrm{NaHCO}_{3}-\mathrm{Po}\right.$ and $\left.\mathrm{NaOH}-\mathrm{Po}\right)$ need to be mineralized for plant uptake (Spohn and Kuzyakov 2013). Inorganic $\mathrm{P}$ solubilization and organic P mineralization are mainly controlled by phosphorus solubilizing microorganisms (PSMs) that secrete organic acid and synthesize various phosphatase enzymes (Richardson et al. 2009). Acid phosphatases (AiP; EC3.1.3.2) and alkaline phosphatases (AlP; EC3.1.3.1) are two non-specific phosphohydrolases able to hydrolyze simple phosphate monoesters to orthophosphate. The AiP can be excreted by plant roots, nodules, and soil microbes, while the production of AlP is carried out by soil bacteria and some fungi (Fraser et al. 2017).

Many studies have found that PSM species showed various responses to fumigant composition (Pecina et al. 2016; Zhang et al. 2019; Huang et al. 2020a) and application rates (Huang et al. 2020b). For example, Pecina et al. (2016) proved that the population of Pseudomonas ssp. and Bacillus ssp. increased immediately after CP fumigation in intensive tomato production fields with alkaline soil. Dangi et al. (2017) concluded that the proportion of arbuscular mycorrhizal fungi (AMF) was lower in sites with 15, 33, and 39 years of annual methyl bromide fumigation as compared to non-fumigated sites. The variation of PSMs leads to a change in $P$ solubilizing genes and phosphatase enzyme activities, which essentially determine soil $\mathrm{P}$ availability. Recently, researchers like Huang et al. (2020a, b) found that soil fumigation using chloropicrin and dazomet significantly increased the plant available $\mathrm{P}$ content in soil and the amount of leached soil $\mathrm{P}$ during the first 2 weeks of incubation. No significant difference was observed for the amounts of available $P$ and leached $P$ after 30 days, regardless of the concentrations of chloropicrin and dazomet applied.

However, the response patterns of soil P cycling to longterm repeated soil fumigation in agricultural systems are still far from clear. Understanding the soil P transformation in fields exposed to long-term soil fumigation is crucial in providing deeper insight into the interaction between soil 
fumigation and soil phosphorus availability. Therefore, in this study, we aimed to understand the effects of repeated chloropicrin fumigation on ginger yield, $\mathrm{P}$ uptake, soil phosphatase activity, and soil $\mathrm{P}$ fractions in a real-world field. We hypothesized that the repeated chloropicrin fumigation could increase ginger yield, but decrease the soil available $\mathrm{P}$ contents by increasing ginger $\mathrm{P}$ uptake.

\section{Material and methods}

\subsection{Experiment design}

The sampling sites were located in Anqiu, in the Shandong Province of China $\left(36^{\circ} 21^{\prime} 42^{\prime \prime \prime} \mathrm{N}, 119^{\circ} 10^{\prime} 38^{\prime \prime} \mathrm{E}\right.$; Fig. 1), a region with a temperate continental monsoon climate. The mean temperature is $12.2^{\circ} \mathrm{C}$ and the mean annual precipitation is $646.3 \mathrm{~mm}$.

Ginger production fields belonging to the local smallholder farmers in a plain region were selected (Fig. 1). The historical cropping systems in all farms were wheat-corn rotations. These systems were changed at different years to monoculture ginger production in 2012, 2016, and 2019. The application of the soil fumigant chloropicrin to prevent soil-borne diseases has started with the cultivation of ginger production. We selected fields with 0,3 , and 7 years of annual chloropicrin fumigation (F0, F3, and F7; 3 replicates each). The size of the replicate field ranges from 530 to 1300 $\mathrm{m}^{2}$. Five soil samples were taken from each replicate field to take soil heterogeneity into consideration and were analyzed separately.

Agricultural management practices, such as tillage, then fumigation, rides and furrows, fertilization with biofertilizers (microbial biocontrol agent) before plantation, fertilization with compound mineral $\left(\mathrm{N}-\mathrm{P}_{2} \mathrm{O}_{5}-\mathrm{K}_{2} \mathrm{O}: 18-15-22\right)$ and organic fertilizers (soybean meal), and open ditch irrigation during a vegetation period of 8 months, were similar in all fields. During the entire ginger growth period, the total $\mathrm{P}$ input was about $48 \mathrm{~kg} \mathrm{ha}^{-1}$.

The soils are classified as sandy loam (sand: 52.4 69.8\%, silt: $16.1 \sim 37.4 \%$, clay: $10.3 \sim 20.7 \%$; International soil classification system). The initial soil properties are presented in Table 1.

Chloropicrin (Dalian Lvfeng Chemical Co. Ltd. (Dalian, China)) was applied in all selected fields before ginger planting in March 2019. Chloropicrin was injected 15 to $30 \mathrm{~cm}$ into the soil using a specialized machine and the average application rate was $375 \mathrm{~kg} \mathrm{ha}^{-1}$. The fields were then
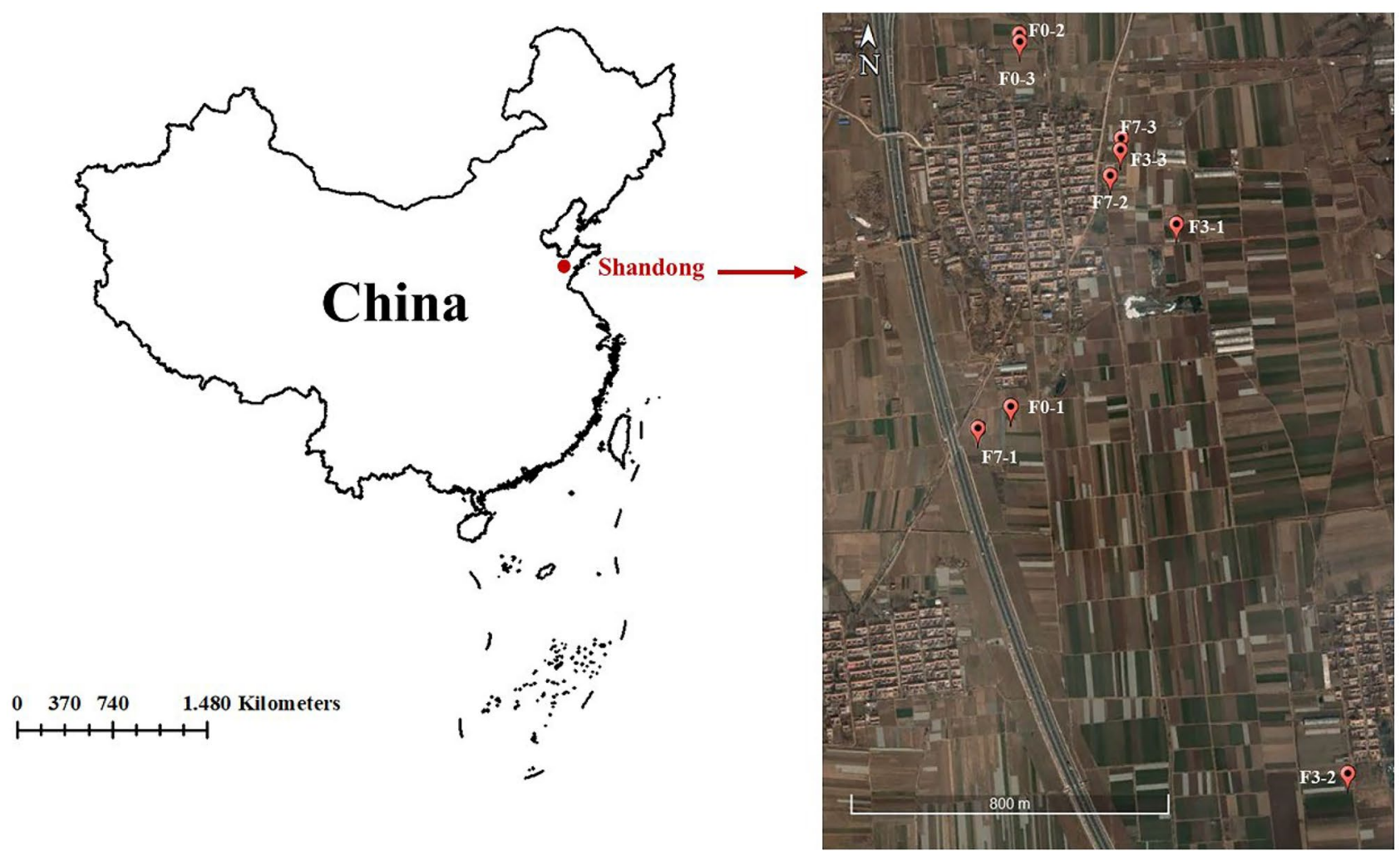

Fig. 1 The locations of sampling sites. The red dot names with Shandong indicate the location of the sampling region in China. The picture on the right is a screenshot of the sampling fields from Google

Earth. F0, F3, and F7 represent fields with 0, 3, and 7 years of chloropicrin fumigation history before 2019, with three replicated fields for each of them (F0-1, F0-2, F0-3; F3-1, F3-2, F3-3; F7-1, F7-2, F7-3) 
Table 1 Soil physiochemical properties in the selected fields at the beginning of the experiment in 2019

\begin{tabular}{lllll}
\hline Field & $\mathbf{p H}\left(\mathbf{H}_{\mathbf{2}} \mathbf{O}\right)^{\mathbf{a}}$ & $\mathbf{S O M}\left(\mathbf{g ~ k g}^{\mathbf{- 1}}\right)^{\mathbf{b}}$ & $\mathbf{T P}\left(\mathbf{g ~ k g}^{-\mathbf{1}}\right)^{\mathbf{c}}$ & $\mathbf{T N}\left(\mathbf{g ~ k g}^{\mathbf{- 1}}\right)^{\mathbf{d}}$ \\
\hline F0-1 & $5.1 \pm 0.1$ & $18.3 \pm 2.4$ & $1.5 \pm 0.3$ & $0.7 \pm 0.0$ \\
F0-2 & $4.9 \pm 0.2$ & $25.3 \pm 3.4$ & $1.6 \pm 0.2$ & $0.6 \pm 0.1$ \\
F0-3 & $6.3 \pm 0.3$ & $20.8 \pm 1.1$ & $1.2 \pm 0.1$ & $0.3 \pm 0.2$ \\
F3-1 & $6.6 \pm 0.2$ & $21.4 \pm 5.8$ & $2.2 \pm 0.3$ & $0.7 \pm 0.1$ \\
F3-2 & $7.7 \pm 0.2$ & $24.9 \pm 3.0$ & $2.4 \pm 0.3$ & $0.8 \pm 0.1$ \\
F3-3 & $7.1 \pm 0.1$ & $23.2 \pm 3.0$ & $2.3 \pm 0.2$ & $0.6 \pm 0.1$ \\
F7-1 & $5.7 \pm 0.3$ & $17.2 \pm 1.5$ & $1.4 \pm 0.2$ & $0.8 \pm 0.1$ \\
F7-2 & $6.1 \pm 0.2$ & $24.4 \pm 2.4$ & $2.4 \pm 0.1$ & $1.2 \pm 0.1$ \\
F7-3 & $5.5 \pm 0.3$ & $27.0 \pm 2.5$ & $1.7 \pm 1.5$ & $1.0 \pm 0.1$ \\
\hline
\end{tabular}

F0, F3, and F7 represent fields with 0-, 3-, and 7-year chloropicrin fumigation history before 2019, with 3 replicated fields for each of them. Data represents the means of five replicates in each field with standard deviation

${ }^{\mathrm{a}} \mathrm{pH}\left(\mathrm{H}_{2} \mathrm{O}\right)$ soil:ultra-pure water with a ratio of $1: 2.5$

${ }^{\mathrm{b}} \mathrm{SOM}$ soil organic matter $\left(\mathrm{g} \mathrm{kg}^{-1}\right)$, colorimetric method after $\mathrm{H}_{2} \mathrm{SO}_{4}-\mathrm{K}_{2} \mathrm{CrO}_{7}$ oxidation (Sun et al. 2019)

${ }^{\mathrm{c}} \mathrm{TP}$ total phosphorus $\left(\mathrm{g} \mathrm{kg}^{-1}\right)$, analyzed by inductively coupled plasmaoptical emission spectroscopy (ICP-OES) after $\mathrm{HNO}_{3}-\mathrm{HF}-\mathrm{H}_{2} \mathrm{O}_{2}$ digestion at $180{ }^{\circ} \mathrm{C}$ using a MARS 5 Xpress microwave system (CEM, USA)

${ }^{\mathrm{d}} T N$ total nitrogen $\left(\mathrm{g} \mathrm{kg}^{-1}\right)$, measured using an elemental analyzer

covered by plastic films for 2 weeks. The plastic films were removed to release built-up gas 1 week before planting. A previous study showed that the half-life of $\mathrm{CP}$ was about 6 days under the following conditions: an application rate of $392 \mathrm{~kg} \mathrm{ha}^{-1}$ under $10{ }^{\circ} \mathrm{C}, 8 \%$ soil moisture content, and $1 \%$ soil organic matter content (Ashworth and Yates 2019), which was similar to conditions in our sampling region.

Topsoil samples from 0-20-cm depth were collected at four stages: before fumigation (05/03/2019), after fumigation (28/03/2019), middle growth period (24/08/2019), and harvest (23/10/2019). Each sample was divided into two subsamples: one was air-dried for soil chemical properties and the other was stored at $4{ }^{\circ} \mathrm{C}$ for analysis of soil phosphatase enzyme activities.

\subsection{The ginger yield and $P$ uptake}

Ginger rhizome yields were estimated at the harvesting stage. Three ginger plants were selected randomly in every field except for the plot F7-3 in which all ginger plants died due to a soil-borne disease before sampling could be carried out. For ginger plant samples, the biomass weight of fresh shoots and rhizomes were measured by gravimetric analysis. The yield of ginger rhizome was estimated by local farmers, while the yield of ginger shoot was calculated based on the ratio of shoot biomass and rhizome biomass measured from ginger plant samples. The shoot and rhizome samples were separated, and the total $\mathrm{P}$ content was measured using inductively coupled plasma-optical emission spectroscopy (ICP-OES) after $\mathrm{HNO}_{3}-\mathrm{H}_{2} \mathrm{O}_{2}$ digestion (Rosa et al. 2020). The total $\mathrm{P}$ uptake was calculated by multiplying the $\mathrm{P}$ content per unit biomass by the total biomass in each field (Zhao et al. 2019).

\subsection{Soil phosphatase activity}

Soil AiP was measured according to the protocol described by Tabatabai and Bremner (1969). Briefly, $1.0 \mathrm{~g}$ of fresh soil was added $(<2 \mathrm{~mm})$ to a $50-\mathrm{mL}$ flask, along with $0.2 \mathrm{~mL}$ methylbenzene, $1.0 \mathrm{~mL} 0.05 \mathrm{M}$ p-nitrophenyl phosphate, and $4.0 \mathrm{~mL}$ modified universal buffer of $\mathrm{pH} 6.5$, mixed and incubated at $37{ }^{\circ} \mathrm{C}$ for $1 \mathrm{~h}$. Then, $1.0 \mathrm{~mL} 0.5 \mathrm{M} \mathrm{CaCl}_{2}$ and $4.0 \mathrm{~mL} 0.5 \mathrm{M} \mathrm{NaOH}$ were added to terminate the reaction and then the mixture was filtrated. Absorbance of the filtrate was measured using a spectrophotometer at $410 \mathrm{~nm}$. To measure AlP activity, the universal buffer of $\mathrm{pH} 6.5$ was replaced by a universal buffer of $\mathrm{pH} 11$ (Zhao et al. 2019).

\section{4 $P$ fractions in soil}

Soil Olsen-P proposed by Olsen et al. (1954) was analyzed colorimetrically using the molybdate blue method after extraction with $0.5 \mathrm{~mol} \mathrm{~L}^{-1} \mathrm{NaHCO}_{3}$ at $\mathrm{pH} 8.5$ for $30 \mathrm{~min}$ (Hu et al. 2012). Soil $\mathrm{P}$ fractions were sequentially extracted using the methods slightly modified according to Tiessen (2006). Briefly, $0.5 \mathrm{~g}$ of air-dried soil $(<0.25 \mathrm{~mm})$ was put into a $50-\mathrm{mL}$ centrifuge tube and sequentially extracted with (1) ultrapure water with two anion exchange resin membrane strips $(1 \mathrm{~cm} \times 2 \mathrm{~cm})$ converted to the bicarbonate form, (2) $0.5 \mathrm{M} \mathrm{NaHCO}_{3}$, and (3) $0.1 \mathrm{M} \mathrm{NaOH}$ and $1 \mathrm{M} \mathrm{HCl}$ at $25^{\circ} \mathrm{C}$ for $16 \mathrm{~h}$ (180 rpm). The soil suspension was centrifuged at $10,000 \mathrm{~g}$ for $10 \mathrm{~min}$ at $0{ }^{\circ} \mathrm{C}$ and decanted. After adjusting $\mathrm{pH}$, inorganic $\mathrm{P}(\mathrm{Pi})$ fractions in each extract were measured using the molybdate ion colorimetry method at $700 \mathrm{~nm}$ (Costa et al. 2016; Zhou et al. 2018). Total P in the extracts was determined using ICP-OES while the organic $\mathrm{P}$ fractions ( $\mathrm{Po}$ ) were calculated as the difference between TP and $\mathrm{Pi}$. The $\mathrm{P}$ fractions were interpreted as resin- $\mathrm{P}, \mathrm{NaHCO}_{3}-\mathrm{P}$ $\left(\mathrm{NaHCO}_{3}-\mathrm{Pi}\right.$ and $\left.\mathrm{NaHCO}_{3}-\mathrm{Po}\right), \mathrm{NaOH}-\mathrm{P}(\mathrm{NaOH}-\mathrm{Pi}$ and $\mathrm{NaOH}-\mathrm{Po}$ ), and occluded $\mathrm{P}$ (HCl-Pi and residual $\mathrm{P}$ ) (Hedley et al. 1982). The concentration of occluded $P$ was estimated by subtracting the sum of the total other $\mathrm{P}$ fractions from the TP concentrations of samples (Koch et al. 2018).

\subsection{Statistical analysis}

The statistical analysis was performed by IBM SPSS Statistic 20. Normality of the measured data and homogeneity of variance were tested using the Kolmogorov-Smirnov and Levene tests $(p>0.05)$. Due to the non-normal distribution 
of Olsen-P, P fraction composition, and AiP and AlP activity values, the non-parametric Kruskal-Wallis analysis with Wilcoxon test $(p<0.05)$ was used to facilitate the comparisons between the different treatments. One-way analysis of variance (ANOVA) with Fisher's least significant difference (LSD) at $p<0.05$ was applied to normally distributed data (ginger P uptake). Redundancy analysis (RDA) was performed to establish the relationship among $\mathrm{P}$ fractions (response variables) and soil properties (explanatory variables) using Origin 2020. All of the figures were created using Origin 2020.

\section{Results}

\subsection{The ginger yield and $P$ uptake}

The average ginger rhizome yields in F0 and F3 were almost the same at $70.0 \mathrm{t} \mathrm{ha}^{-1}$, while the rhizome yield of F7 was the lowest at $37.5 \mathrm{t} \mathrm{ha}^{-1}$ (Fig. 2a).

The total ginger $\mathrm{P}$ uptake showed similar trends as ginger biomass (Fig. 2b). There was no significant difference in shoot $\mathrm{P}$ uptakes between F0 and F3 with 11.0 and $10.1 \mathrm{~kg} \mathrm{ha}^{-1}$, respectively, which were significantly higher than shoot $\mathrm{P}$ uptake in F7 $\left(5.9 \mathrm{~kg} \mathrm{ha}^{-1}\right)$. No significant difference was observed for root P uptake between F0 and F3

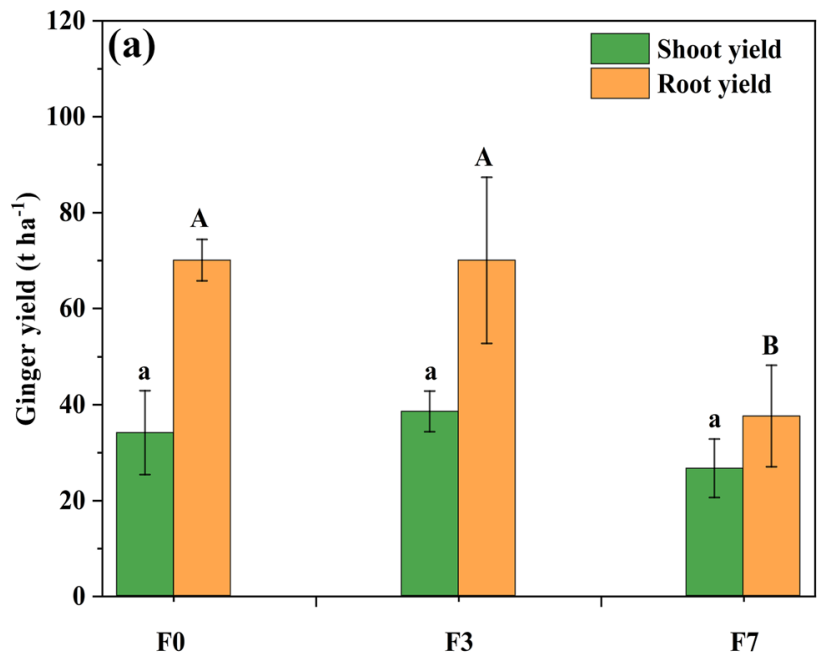

Fig. 2 The average of ginger yield (a) and total ginger P uptake (b) after harvest. F0, F3, and F7 represent fields with 0,3 , and 7 years of chloropicrin fumigation history before 2019, with 3 replicated fields for each of them. Legends indicate the average ginger shoot (light green) and root (light orange) yield per hectare in Fig. 2(a) and the total $\mathrm{P}$ content in ginger shoots (light green) and roots (light orange) per hectare in Fig. 2(b). Column represents the average of replicates
(F0: $19.3 \mathrm{~kg} \mathrm{ha}^{-1}$; F3: $23.1 \mathrm{~kg}^{-1}$ ), while the root P uptake was significantly lower in F7 $\left(10.9 \mathrm{~kg} \mathrm{ha}^{-1}\right)$.

\subsection{Phosphatase activity}

The average AiP activity was significantly higher in F0 than F3 and F7 during the entire ginger growth period (Fig. 3a). In F0, the average AiP activity changed from $24.0 \mathrm{mg} p$-nitrophenol $\mathrm{g}^{-1} \mathrm{~h}^{-1}$ before fumigation to $14.6 \mathrm{mg} p$-nitrophenol $\mathrm{g}^{-1} \mathrm{~h}^{-1}$ after fumigation, and recovered to $19.6 \mathrm{mg} p$-nitrophenol $\mathrm{g}^{-1} \mathrm{~h}^{-1}$ after harvest. There were no significant differences between F3 and F7 (12.1 to $13.8 \mathrm{mg} p$-nitrophenol $\mathrm{g}^{-1} \mathrm{~h}^{-1}$ ) except for the samples taken after fumigation. For samples collected after fumigation, the average AiP activity was significantly higher in F3 (13.9 $\mathrm{mg} p$-nitrophenol $\mathrm{g}^{-1} \mathrm{~h}^{-1}$ ) than in F7 (9.4 $\mathrm{mg} p$-nitrophenol $\mathrm{g}^{-1} \mathrm{~h}^{-1}$ ).

For samples collected before fumigation, the average AlP activity was significantly higher in F3 (14.1 $\mathrm{mg} p$-nitrophenol $\left.\mathrm{g}^{-1} \mathrm{~h}^{-1}\right)$ than in F0 (6.1 $\mathrm{mg} p$-nitrophenol $\left.\mathrm{g}^{-1} \mathrm{~h}^{-1}\right)$ and F7 (6.5 $\mathrm{mg} p$-nitrophenol $\mathrm{g}^{-1} \mathrm{~h}^{-1}$ ), while there was no significant difference between F0 and F7 (Fig. 3b). For samples collected after fumigation, the average AlP activity in F3 (20.6 mg $p$-nitrophenol $\mathrm{g}^{-1} \mathrm{~h}^{-1}$ ) was still significantly higher than in F0 (7.7 $\mathrm{mg} p$-nitrophenol $\left.\mathrm{g}^{-1} \mathrm{~h}^{-1}\right)$. For samples collected during the middle growth period and harvest, no significant difference in the average AlP activity (14.9 to

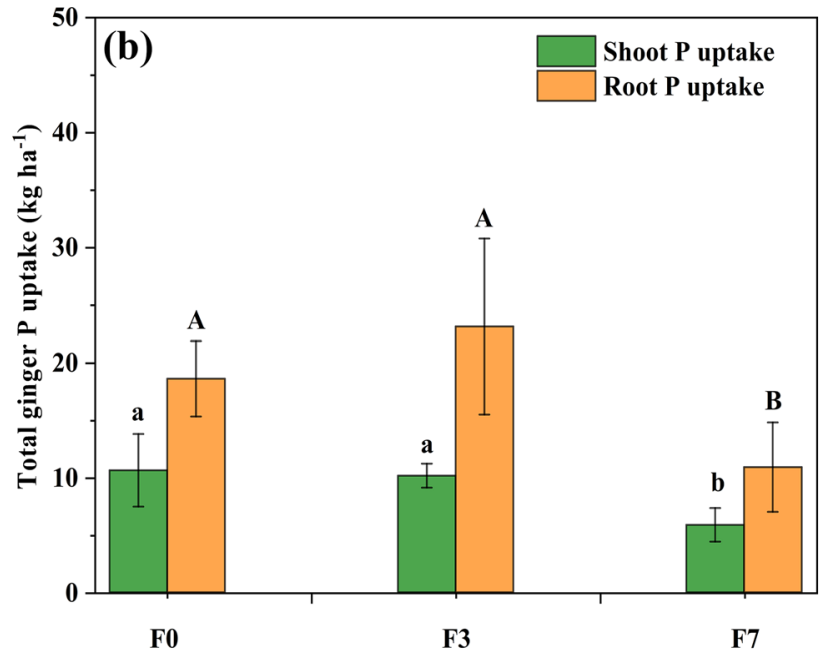

with standard deviation. In Fig. 2(a), the uppercase letters (A and B) and lowercase letters ( $a$ and $b$ ) indicate the significant difference in ginger root and shoot yield among three treatments, respectively. In Fig. 2(b), the uppercase letters (A and B) and lowercase letters (a and b) indicate the significant difference in ginger root and shoot $\mathrm{P}$ uptake among three treatments, respectively. Treatments with the same letter had no significant difference (ANOVA with LSD test, $p<0.05$ ) 


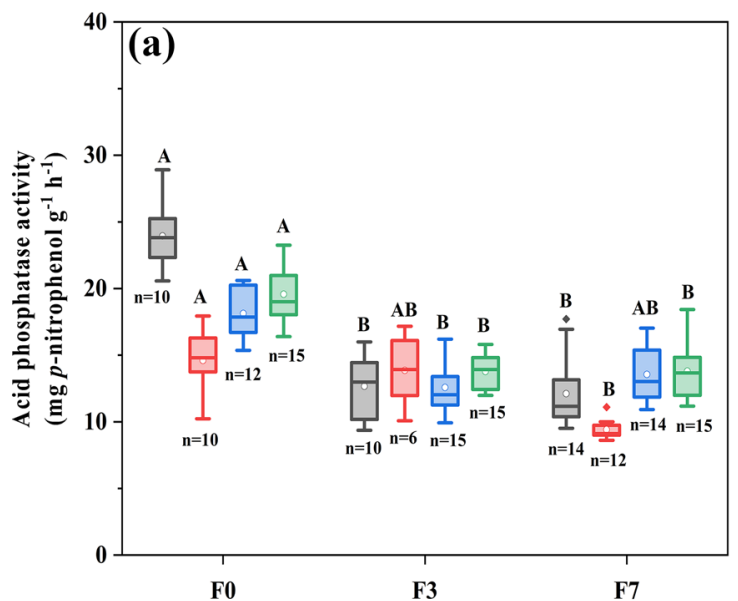

Fig. 3 Soil acid (a) and alkaline (b) phosphatase activity in the three treatments and sampling times. F0, F3, and F7 represent fields with 0,3 , and 7 years of chloropicrin fumigation history before 2019, with 3 replicated fields for each of them. Legend indicates the sampling time, including before fumigation (gray), after fumigation (red), mid-

$21.6 \mathrm{mg}$ p-nitrophenol $\mathrm{g}^{-1} \mathrm{~h}^{-1}$ ) was observed among three treatments.

\subsection{Variation of soil $P$ in the different treatments}

For samples collected before fumigation, the content of soil Olsen-P were $129.8,106.2$, and $148.3 \mathrm{mg} \mathrm{kg}^{-1}$ in F0, F3, and F7, respectively, and the differences among the three

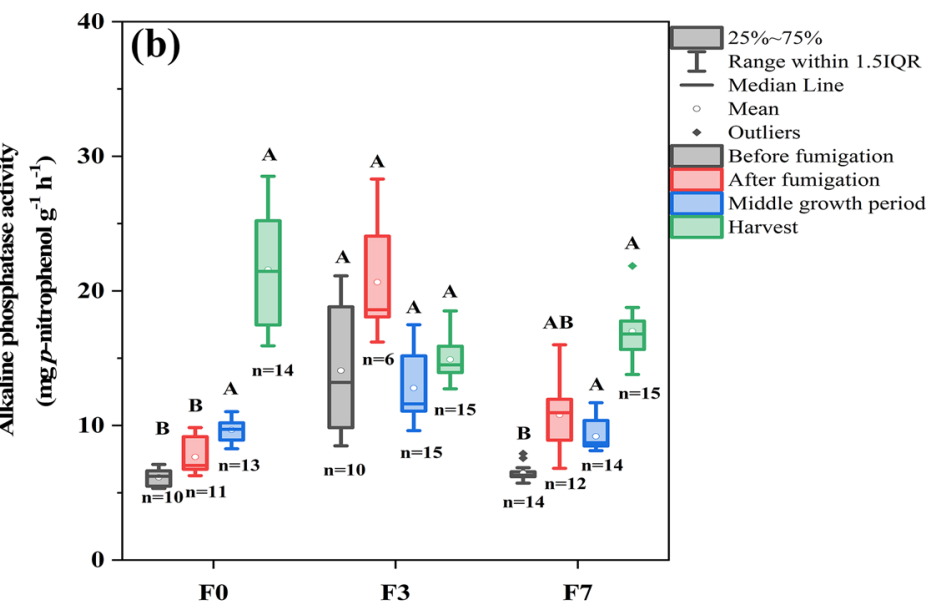

dle growth period (blue), and harvest (green). $n$ is the number of actual samples in the corresponding box. The uppercase letters (A and $\mathrm{B}$ ) indicate the significant difference among the three treatments during each sampling time (Wilcoxon test, $p<0.05$ )

fumigated fields were not statistically significant (Fig. 4). During the whole ginger growth period, the application of chemical fertilizers by local farmers and the $\mathrm{P}$ uptake by ginger caused the variation of soil Olsen-P content to be 111.1 162.1, 87.1 127.2, and 137.8 203.6 $\mathrm{mg} \mathrm{kg}^{-1}$ in F0, $\mathrm{F} 3$, and F7, respectively.

The average TP contents were significantly lower in F0 (1179 to $1523 \mathrm{mg} \mathrm{kg}^{-1}$ ) than that in F3 (1994 to
Fig. 4 Soil Olsen-P in different fields and sampling times. F0, F3, and F7 represent fields with 0,3 , and 7 years of chloropicrin fumigation history before 2019 , with 3 replicated fields for each of them. Legend indicates the sampling time, including before fumigation (gray), after fumigation (red), middle growth period (blue), and harvest (green). The number of samples for every box were $15(n=15)$ except for samples of $\mathrm{F} 0$ and $\mathrm{F} 3$ before fumigation $(n=10)$. The uppercase letters (A and B) indicate the significant difference among the three treatments during each sampling time (Wilcoxon test, $p<0.05$ )

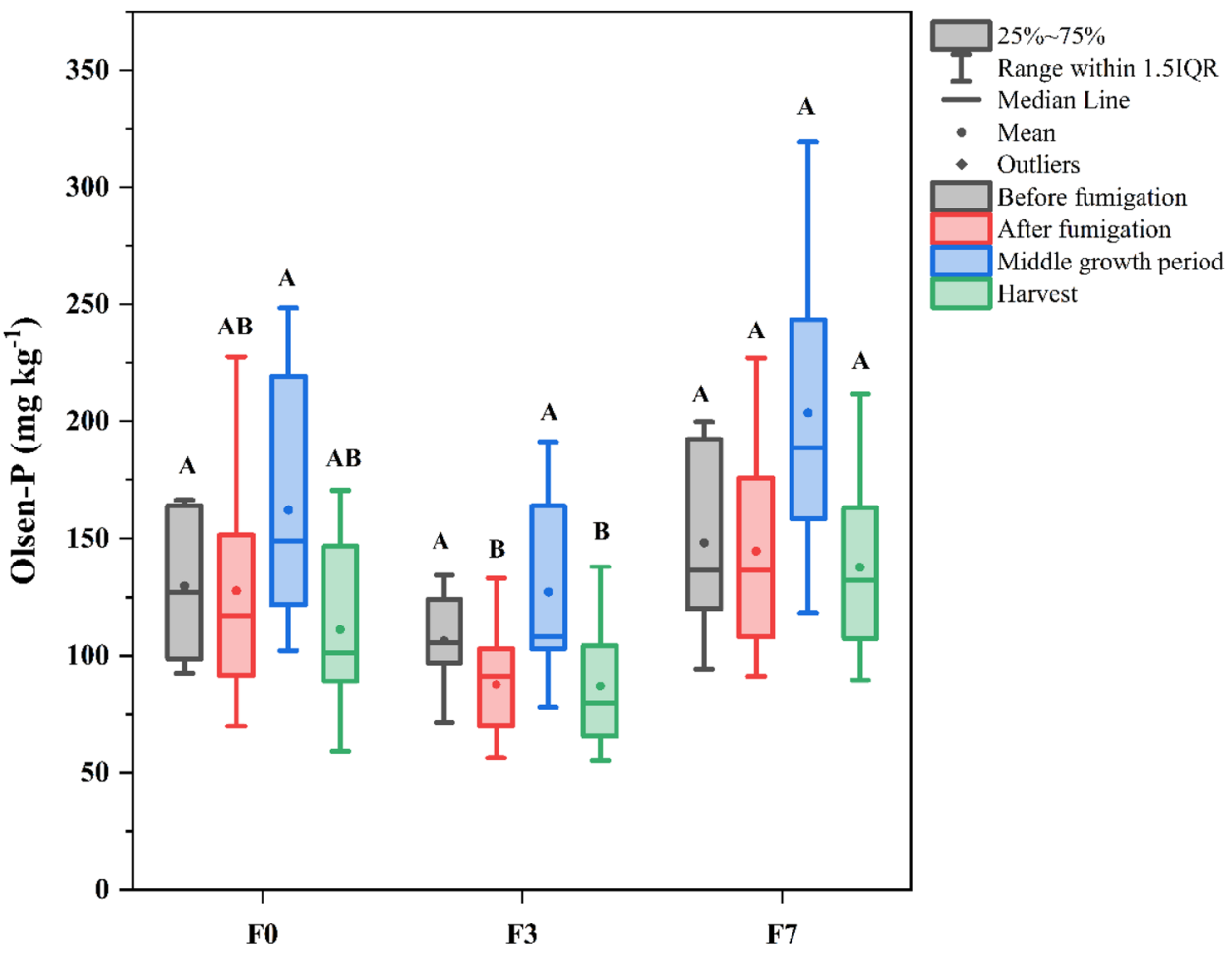


$2487 \mathrm{mg} \mathrm{kg}^{-1}$ ) and F7 (1967 to $2257 \mathrm{mg} \mathrm{kg}^{-1}$ ) during the whole growing period. After measuring the total phosphorus (TP) contents, different soil P fractions were extracted using modified Hedley's sequential extraction method (Fig. S1).

For each of the $\mathrm{P}$ fractions, unavailable Occluded-P showed similar variation as TP with significantly lower contents in F0 (461 to $738 \mathrm{mg} \mathrm{kg}^{-1}$ ) than in F3 (1485 to $2019 \mathrm{mg} \mathrm{kg}^{-1}$ ) and F7 (1237 to $1522 \mathrm{mg} \mathrm{kg}^{-1}$ ). Significantly lower contents of NaOH-Po and NaOH-Pi were found in $\mathrm{F} 3$ (NaOH-Po: 20 to $153 \mathrm{mg} \mathrm{kg}^{-1}$; NaOH-Pi: 65 to $89 \mathrm{mg} \mathrm{kg}^{-1}$ ) as compared to F0 (NaOH-Po: 32 to $273 \mathrm{mg} \mathrm{kg}^{-1}$; NaOH-Pi: 159 to $204 \mathrm{mg} \mathrm{kg}^{-1}$ ) and F7 (NaOH-Po: 28 to $275 \mathrm{mg} \mathrm{kg}^{-1}$; $\mathrm{NaOH}-\mathrm{Pi}: 133$ to $159 \mathrm{mg} \mathrm{kg}^{-1}$ ). There were no significant differences in the contents of $\mathrm{NaHCO}_{3}-\mathrm{Po}$ among the three treatments, while the contents of $\mathrm{NaHCO}_{3}-\mathrm{Pi}$ and resin-P were significantly higher in F7 than in F0 and F3 (Fig. S1).

The proportions of soil $\mathrm{P}$ fraction to total $\mathrm{P}$ were also calculated to eliminate the basic differences among fields by dividing the soil total $\mathrm{P}$ contents by every $\mathrm{P}$ fraction content (Fig. 5). For samples collected before fumigation, the proportion of resin-P was significantly lower in $\mathrm{F} 3$ (7.6\%) than in F0 (12.1\%) and F7 (12.4\%). The $\mathrm{NaHCO}_{3}-\mathrm{Pi}$ proportion appeared to have the same variation as resin-P with $6.7 \%, 4.5 \%$, and $6.6 \%$ in $\mathrm{F} 0, \mathrm{~F} 3$, and $\mathrm{F} 7$, respectively. The proportion of resin-P and $\mathrm{NaHCO}_{3}$-Pi remained significantly lower in F3 than F0 and F7 during the whole growth period. The proportion of $\mathrm{NaHCO}_{3}$-Po was significantly higher in F0 with $21.2 \%$ as compared to the proportions measured in F3 (10.6\%) and F7 (11.2\%) before fumigation. After fumigation, the proportions of $\mathrm{NaHCO}_{3}$-Po became $19.7 \%, 7.7 \%$, and $18.1 \%$ in F0, F3, and F7, respectively. During the middle growth period, there was no significant difference in the proportions of $\mathrm{NaHCO}_{3}$-Po among three treatments. However, the proportions of $\mathrm{NaHCO}_{3}-\mathrm{Po}$ were $8.4 \%$ in $\mathrm{F} 0$ but still remained at $2.8 \%$ and $2.9 \%$ in $\mathrm{F} 3$ and F7 after harvest. The proportion of $\mathrm{NaOH}-\mathrm{Pi}$ was significantly lower in F3 with $3.9 \%$ and there were no significant differences between F0 (12.7\%) and F7 (8.2\%) before fumigation. The proportion of NaOH-Pi remained almost constant through the whole sampling time in all three treatments. However, $\mathrm{NaOH}-\mathrm{Po}$ showed similar changes as $\mathrm{NaHCO}_{3}$-Po among different $\mathrm{CP}$ fumigation fields and sampling times. The proportions of NaOH-Po were $2.0 \%$, $0.9 \%$, and $1.4 \%$ before fumigation which increased to $7.5 \%$, $2.5 \%$, and $5.0 \%$ in F0, F3, and F7 fields, respectively, after fumigation. The $\mathrm{NaOH}-\mathrm{Po}$ proportion increased during the whole ginger growth period and reached up to $19.4 \%, 6.9 \%$, and $13.0 \%$ in F0, F3, and F7 fields, respectively, after harvest. The proportion of occluded-P showed opposite trends to available $\mathrm{P}$ fractions with significantly higher values in F3 with $72.5 \%$ and there were no significant differences between F0 (45.3\%) and F7 (60.1\%) for samples before fumigation. The sampling time did not have a significant influence on the proportion of occluded-P.
Fig. 5 Proportions of various soil $\mathrm{P}$ fraction to total $\mathrm{P}$ in the three treatments and four sampling times. F0, F3, and F7 represent fields with $0-$, $3-$, and 7-year chloropicrin fumigation history before 2019, with 3 replicated fields for each of them. Sampling times were (1) before fumigation, (2) after fumigation, (3) middle growth period, and (4) harvest. Legend indicates the soil $\mathrm{P}$ fractions, including resin-P (orange), $\mathrm{NaHCO}_{3}-\mathrm{Pi}$ (green), $\mathrm{NaHCO}_{3}$-Po (purple), $\mathrm{NaOH}-\mathrm{Pi}$ (yellow), NaOH-Po (blue), and occluded-P (red).

The lowercase letters $(\mathrm{a}, \mathrm{b}$, and c) indicate the significant difference of each $\mathrm{P}$ fraction among the three treatments for every sampling time (Wilcoxon test, $p<0.05$ )

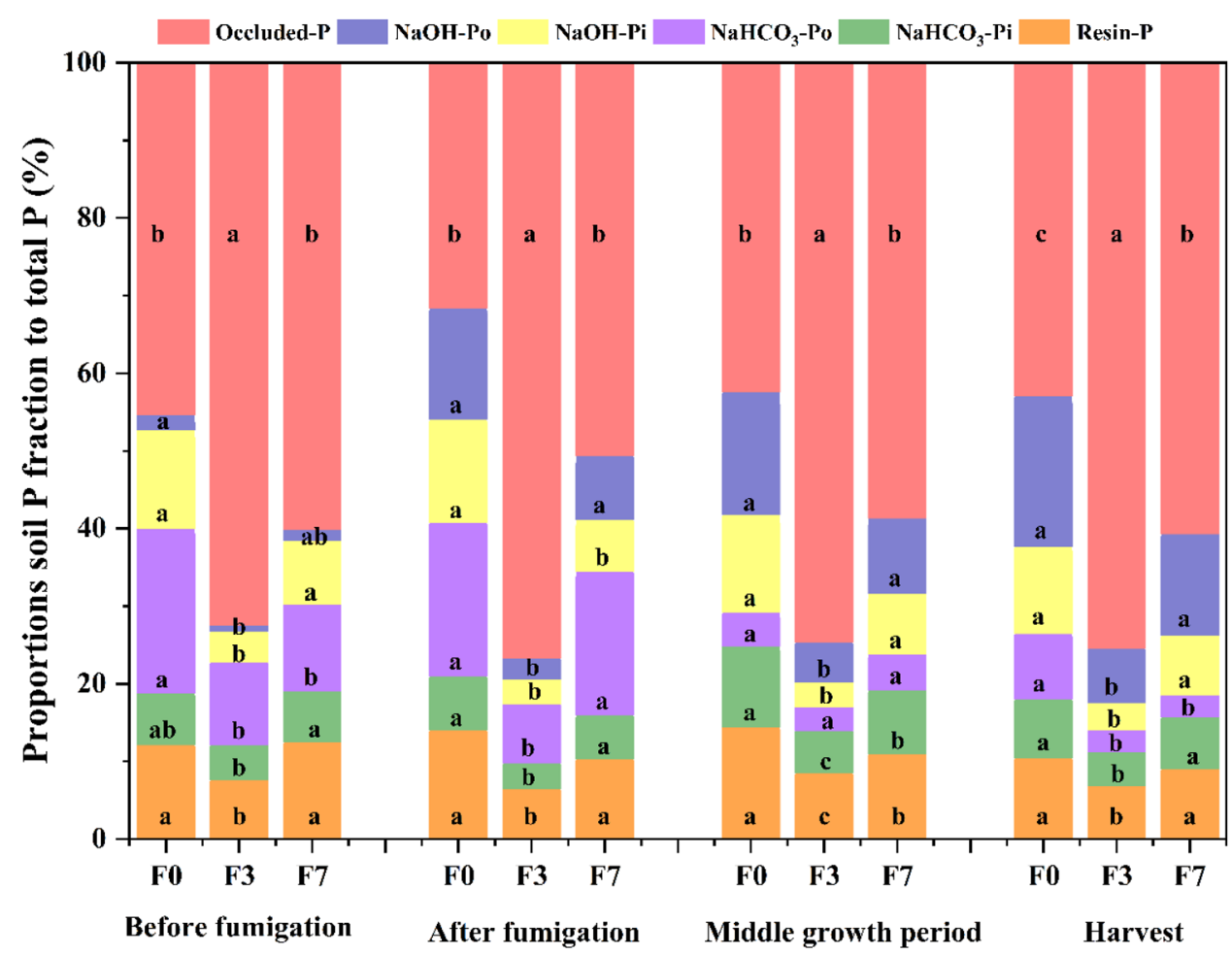




\subsection{Correlation analysis among soil properties, $P$ fractions, and phosphatase enzymes}

The effects of selected soil properties on the composition of soil $\mathrm{P}$ fractions were further analyzed using redundancy analysis (Fig. 6). The first two axes explained over 99\% of the total variation. The results showed that occluded-P fractions were the main forms in $\mathrm{F}$ 3, while other labile $\mathrm{P}$ fractions took the main place in F0 and F7 and no significant differences were observed among these fractions.

According to the indicating arrows, $\mathrm{pH}$, AlP activity, $\mathrm{SOM}$, and TN were highly positively correlated with the proportion of occluded-P to TP. Labile $\mathrm{P}$ fractions (especially $\mathrm{NaHCO}_{3}-\mathrm{Po}$ ) were highly associated with AiP activity.
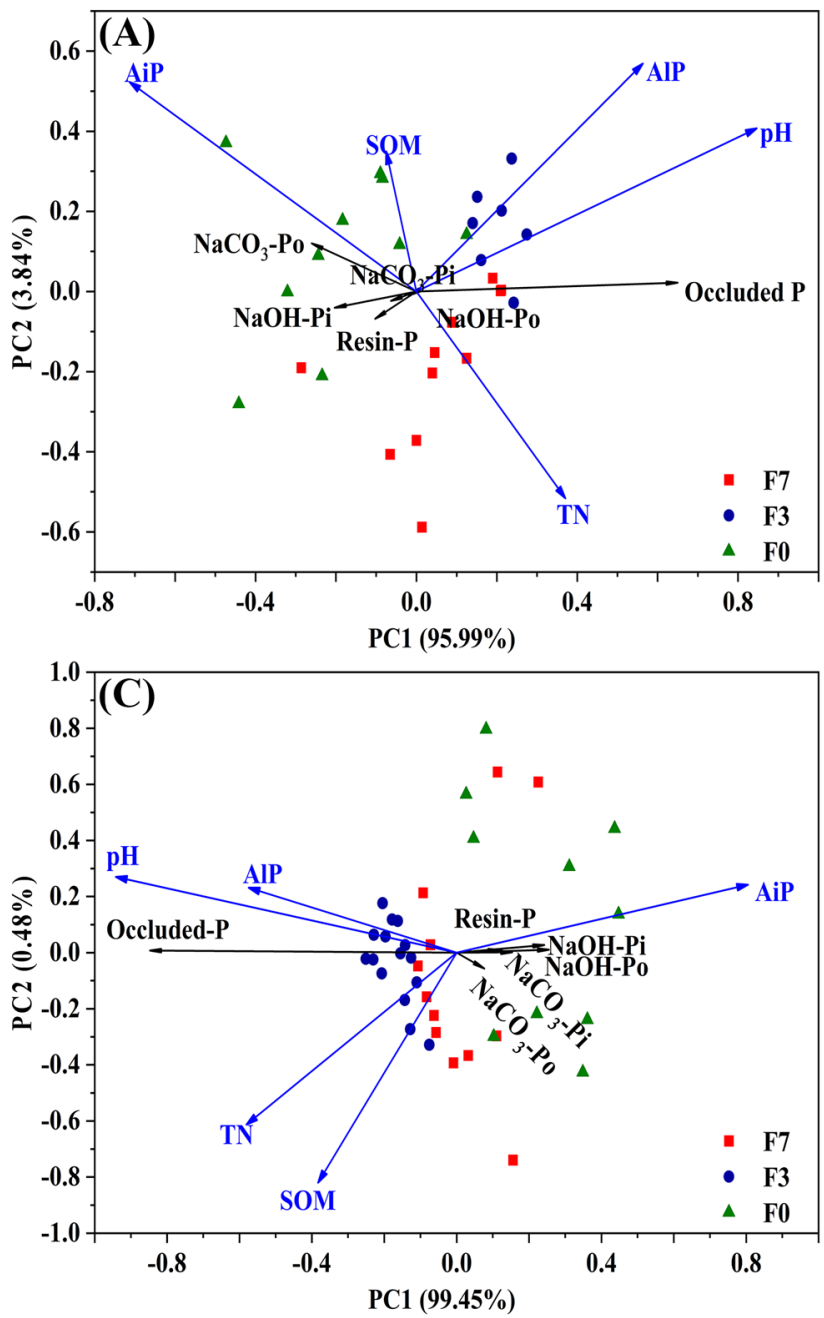

Fig. 6 Redundancy analysis (RDA) of P fractions and soil properties. Every figure refers to the RDA analysis for different sampling times including (A) before fumigation, (B) after fumigation, (C) middle growth period, and (D) harvest. Legend indicates the samples from F0 (green triangle), F3 (blue dot), and F7 (red square) treatments. The

\section{Discussion}

\subsection{The effects of different years of CP fumigation on ginger yield and $P$ uptake}

In this study, we found no significant differences in ginger yields among F0 and F3, while the yields decreased significantly in F7 due to the high level of soil-borne diseases. Similar results were also found in a study by Yao et al. (2006), in which they concluded that apple tree growth and yield were not affected by pre-plant fumigation with a mixture of $78 \%$ dichloropropene $+17 \%$ chloropicrin as compared to untreated controls after 2 years. They suggested that the results might have been related to the decreased inhibitory
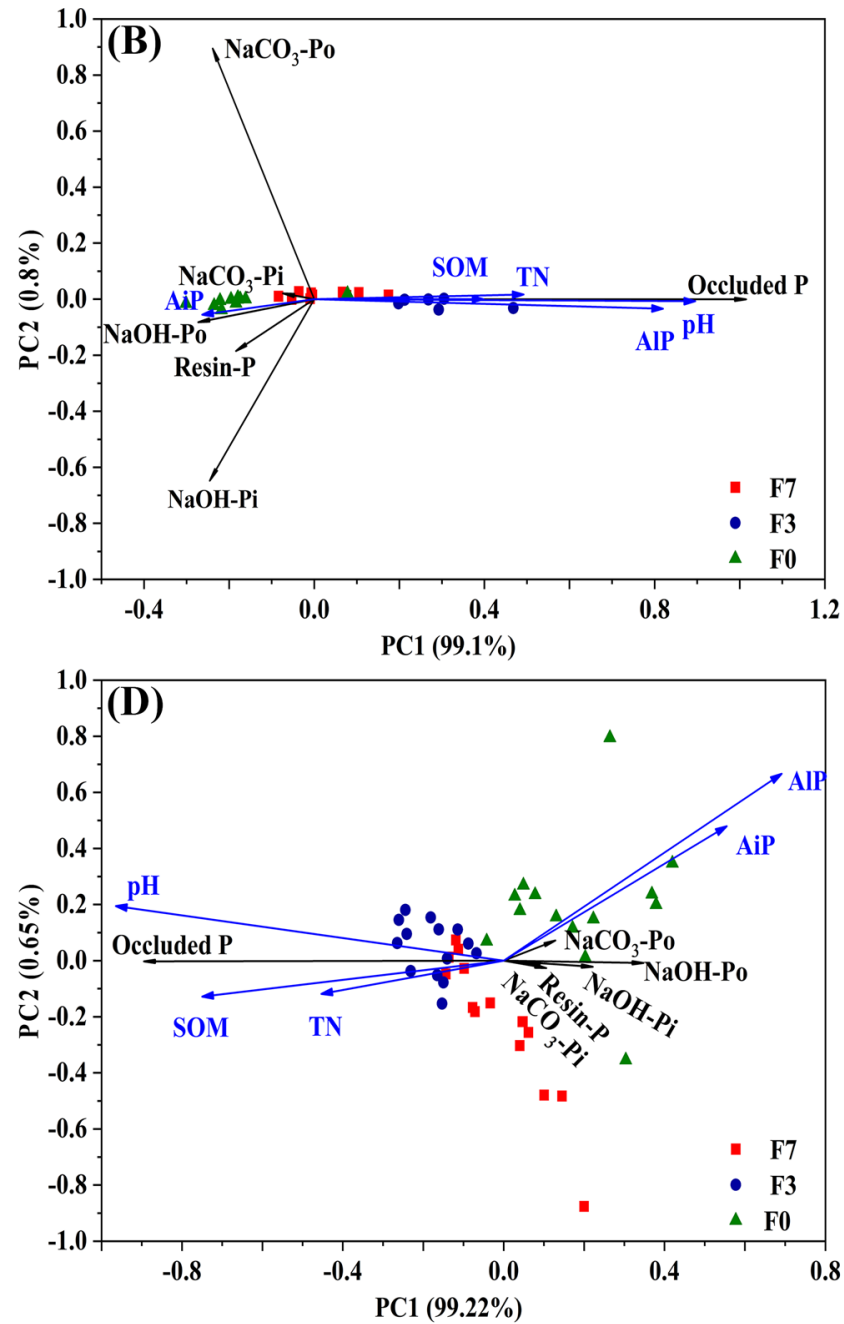

blue arrows are soil properties including $\mathrm{pH}, \mathrm{SOM}, \mathrm{AiP}, \mathrm{AlP}$, and TN. Black arrows are soil $\mathrm{P}$ fractions including resin- $\mathrm{P}, \mathrm{NaHCO}_{3}-\mathrm{Pi}$, $\mathrm{NaHCO}_{3}-\mathrm{Po}, \mathrm{NaOH}-\mathrm{Pi}, \mathrm{NaOH}-\mathrm{Po}$, and occluded-P. The position and length of arrows indicate the direction and strengths of the effects of soil properties on $\mathrm{P}$ fractions 
effects of CP on soil-borne diseases. Our study is also in line with a study conducted by Zhang et al. (2020), who found that the strawberry yield increment varied with different consecutive years of CP fumigation with a maximum of $2.0 \mathrm{~kg} \mathrm{~m}^{-2}$ after 2 years, then decreased to $0.9 \mathrm{~kg} \mathrm{~m}^{-2}$ after 5 years. In the current study, all of the ginger plants in F7-3 field died gradually during the later ginger growth period because of the severe soil-borne diseases occurring there. It was also confirmed by the local ginger growers that the inhibitory effects of CP fumigation on soil-borne diseases decreased greatly after several times of CP applications. This finding underlines the need for other comprehensive agricultural management practices, rather than sole $\mathrm{CP}$ fumigation, to control soil-borne diseases in ginger crops.

The calculated ginger $\mathrm{P}$ uptake showed the same variation as ginger yields with no significant difference among $\mathrm{F} 0$ and $F 3$, while F7 was significantly decreased in this study, which also perhaps contributed to the decrease of arbuscular mycorrhizal fungi (AMF) in CP fumigated soil (Smith and Smith 2011). There is another long-term study based on chronosequence sites which showed that proportions of AMF were significantly lower for sites exposed to 15,33 , and 39 years of fumigation as compared to their non-fumigated counterparts. AMF has been proved to contribute to the mycorrhizal uptake pathway in delivering soil phosphorus to plants (Smith and Smith 2011), so the decrease of AMF could have detrimental effects on plant $\mathrm{P}$ uptake and soil $\mathrm{P}$ availability.

\subsection{The effects of different CP fumigation years on phosphatase activities}

Our study showed that soil AiP activities were significantly lower in F3 and F7 than in F0 except for samples taken after fumigation. The first time of $\mathrm{CP}$ fumigation in $\mathrm{F} 0$ put the most evident inhibitory effects on AiP. Even so, AiP activities recovered more quickly in F0 during the ginger growth. AiP activities in F3 and F7 remained almost constant among the different sampling times, meaning that soil $\mathrm{CP}$ fumigation did not have an obvious influence on AiP activities in F3 and F7.

On the other hand, the highest values for soil AlP activities were observed in F3 except for the samples gathered after harvest. Similar AlP activity values were observed for F0 and F7. It has been proven that AlP increases with the increase of soil pH (Dick et al. 2000). In this study, AlP activity was also significantly positively correlated with soil pH (Fig. S2). Therefore, we assume that the highest $\mathrm{pH}$ values in $\mathrm{F} 3$ are one of the most important reasons for the highest AlP activity there. On the other hand, AlP mainly is originated from soil microorganisms (Acosta-Martínez and Tabatabai 2015). A study by Huang et al. (2020b) found that the application of dazomet fumigant at $50 \mathrm{mg} \mathrm{kg}^{-1}$ showed a transient inhibitory effect on AIP activity before 14 days, which may be due to the decrease of soil phoD gene abundance which is response for the production of AlP. However, in our research, the microbial mechanism of AlP activity changes in different fields needs further study.

\subsection{The effects of different years of $\mathrm{CP}$ fumigation on $P$ fractions}

Soil $\mathrm{P}$ fractions extracted using sequential methods with different extracting agents are indicators of their solubility in soil solution and their availability for plants (Milić et al. 2019). In our experimental fields, the historical cropping system was maize-wheat rotation before the ginger planting. As a cash crop, ginger planting requires more fertilizers input than cereal crops (maize and wheat), causing significantly higher total P levels in F3 and F7 than in F0 (Table 1). Fertilization increased the concentration of $\mathrm{P}$ in the soil solution, thereby enhancing the adsorption of phosphorus by soil particles (Weihrauch and Opp 2018), making soil $\mathrm{P}$ unavailable for ginger plants in F3 and F7 (Fig. S1). Therefore, we did not refer to the total content in this study but we focused on the proportion of each $\mathrm{P}$ fraction to total $\mathrm{P}$ to compare the composition of soil phosphorus (Fig. 5).

The proportion of plant available phosphorus (resin$\mathrm{P}+\mathrm{NaHCO}_{3}-\mathrm{P}+\mathrm{NaOH}-\mathrm{P}$ ) was the lowest in $\mathrm{F} 3$, which may be due to the higher $\mathrm{pH}$ value in $\mathrm{F} 3$ (pH: 6.6 to 7.7) than F0 (pH: 4.9 to 6.3) and F7 (pH: 5.5 to 6.1). The optimum $\mathrm{pH}$ for the highest soil $\mathrm{P}$ availability is 5.5 to 6.0 , because when the soil $\mathrm{pH}$ is lower than 5.0, soil P can form insoluble Fe/Al-P-minerals (Zhou et al. 2018), while in alkaline soil $(\mathrm{pH}>7)$, soil $\mathrm{P}$ combined with $\mathrm{Ca}^{2+}$ and precipitates in the form of Ca-P-minerals (Weihrauch and Opp 2018). The RDA analysis in our study also showed that the proportions of soil occluded-P are highly positively associated with soil $\mathrm{pH}$. Compared with F7, the significantly higher ginger yield and ginger $\mathrm{P}$ uptake in F3 may also attribute to the lower proportions of soil available $\mathrm{P}$. The lowest proportion of soil available $\mathrm{P}$ in $\mathrm{F} 3$ indicates that, although the yields of ginger rhizomes were similar between F0 and F3, the significantly lower proportion of soil available P in F3 may be a key limiting factor for higher ginger yields (Fig. 7).

On the other hand, the significant decrease in ginger yield and $\mathrm{P}$ uptake, and the lack of reduction in the application of phosphate fertilizer in F7, may further cause more available $\mathrm{P}$ fractions to be delayed on the soil surface, because plant uptake is one of the most important outputs of $\mathrm{P}$ in the soil system. Therefore, the low $\mathrm{P}$ use efficiency and high proportions of easily labile $\mathrm{P}$ (resin-P), labile $\mathrm{P}\left(\mathrm{NaHCO}_{3}-\mathrm{P}\right)$, and moderately labile $\mathrm{P}(\mathrm{NaOH}-\mathrm{P})$ in $\mathrm{F} 7$ may cause severe environmental problems such as water eutrophication washed by surface runoff or P leaching into the groundwater system (Zhang et al. 2021). 


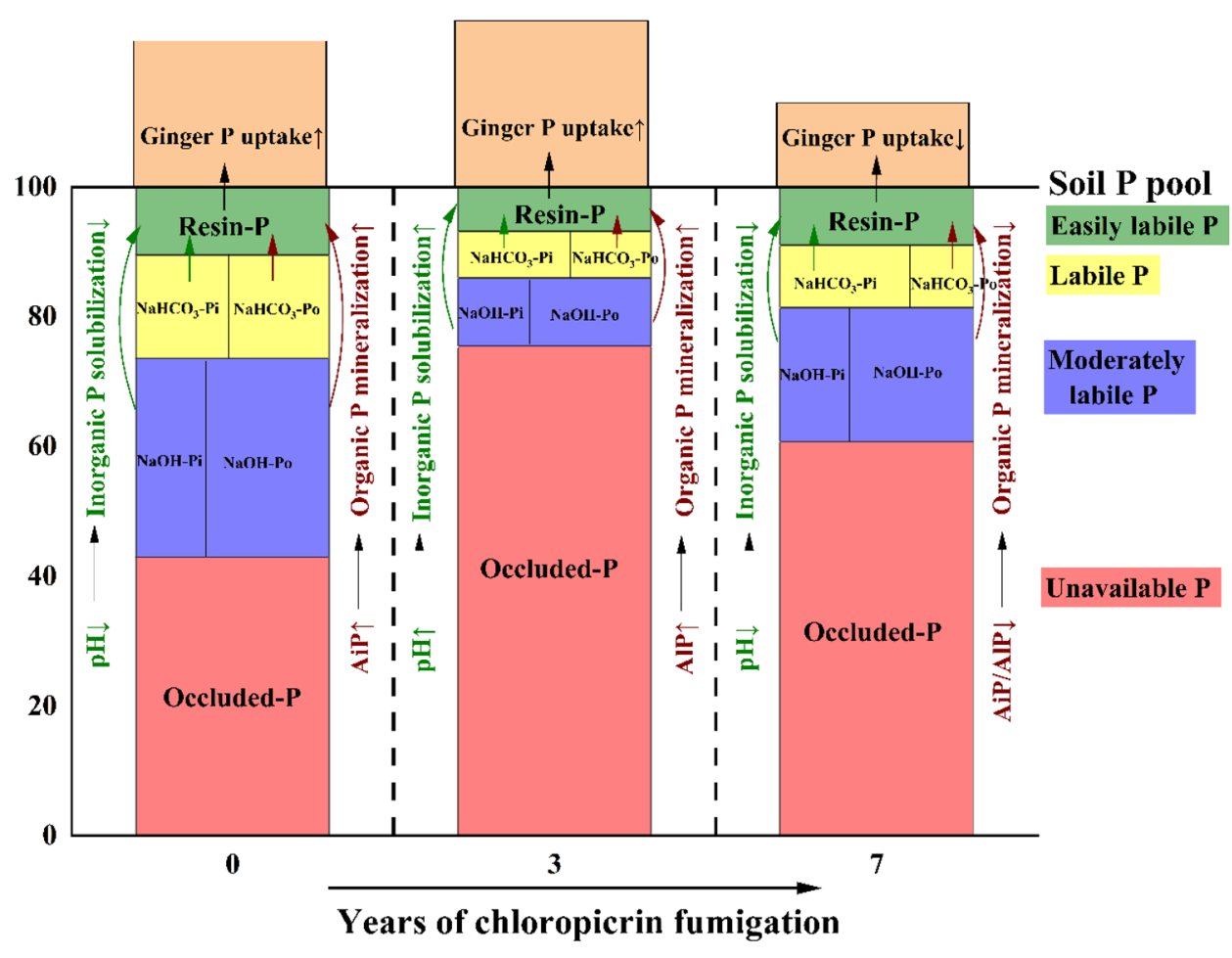

Fig. 7 Schematic diagram of the composition of soil $\mathrm{P}$ pool, the role of soil $\mathrm{pH}$ and phosphatase activity in soil $\mathrm{P}$ transformation, and the ginger P uptake. Data used in this figure is the data measured for the samples collected at harvest. Numbers 0,3 , and 7 represent fields with 0,3 , and 7 years of chloropicrin fumigation before 2019. The numbers at $Y$ axis means the proportions of each $\mathrm{P}$ fraction to total $\mathrm{P}$.
$\mathrm{P}$ fractions are resin- $\mathrm{P}, \mathrm{NaHCO}_{3}-\mathrm{Pi}, \mathrm{NaHCO}_{3}-\mathrm{Po}, \mathrm{NaOH}-\mathrm{Pi}, \mathrm{NaOH}-$ $\mathrm{Po}$, and occluded-P. The distribution of $\mathrm{NaOH}-\mathrm{Pi}$ and $\mathrm{NaOH}-\mathrm{Po}$ as well as the distribution of $\mathrm{NaHCO}_{3}-\mathrm{Pi}$ and $\mathrm{NaHCO}_{3}-\mathrm{Po}$ in the figure were decided according to their own proportions to TP. The soil $\mathrm{P}$ pool was divided into easily labile $\mathrm{P}$, labile $\mathrm{P}$, moderately labile $\mathrm{P}$, and unavailable $\mathrm{P}$ according to their solubility and availability for plant
Among different soil $\mathrm{P}$ fractions, the proportions of organic $\mathrm{P}$ (especially $\mathrm{NaOH}-\mathrm{Po}$ ) increased significantly after CP fumigation again in 2019, which may be caused by the release of microbial organic $P$ from the lysis of soil microorganisms (Fang et al. 2018). The released microbial organic $P$ fractions are then mineralized into available inorganic $\mathrm{P}$ by various soil phosphatases (Acosta-Martínez and Tabatabai 2015). However, CP fumigation also reduced soil phosphatase activity (Huang et al. 2020a), especially AiP in our study, which may then retard the mineralization of organic $\mathrm{P}$ and eventually lead to the accumulation of organic $\mathrm{P}$ in the soil (Fig. 5). However, the detail microbial mechanisms also need to be studied further.

A previous lab incubation study conducted by Huang et al. (2020a) found that CP fumigation significantly increased the proportion of $\mathrm{NaHCO}_{3}$-Po for up to 14 days in acidic soil, and significantly decreased the proportion of $\mathrm{NaHCO}_{3}$-Po up to 49 days in alkaline soil. All of the soil $\mathrm{P}$ fractions recovered to a similar level after 49 days among all $\mathrm{CP}$ treatments in two kinds of soil. They suggested that farmers could reduce the $\mathrm{P}$ fertilizer application in the early stage ( $<30$ days) due to the increase of soil available P. However, our study found that the release of available P by the lysis of dead microbes may not satisfy the increasing demand for soil phosphorus by ginger, at which time, P deficiency may become a major limitation for getting a higher yield in F3. With the increasing of $\mathrm{CP}$ fumigation years, soilborne pathogens may become resistant to CP (Qiao et al. 2010), leading to a serious ginger death in F7. At this time, we should first consider finding another effective method to prevent soil-borne diseases.

\section{Conclusion}

In this field study, we tested the effects of different years of chloropicrin fumigation on ginger yield, phosphatase activities, and soil $\mathrm{P}$ availability. The results showed that, compared with the ginger yield in fields with the first $\mathrm{CP}$ fumigation, no significant difference was observed on the ginger yields in the fields with 3 years of $\mathrm{CP}$ fumigation. However, the contents of soil available $\mathrm{P}$ decreased significantly after 3 years of $\mathrm{CP}$ fumigation, which may become an important limiting factor for the ginger yields. The ginger yield decreased significantly after 7 years of repeated $\mathrm{CP}$ fumigation, at which time, ginger death became the main 
limiting factor for ginger production, and controlling soilborne diseases using a better method rather than sole CP fumigation should be the first consideration. The lower phosphatase activities after repeated $\mathrm{CP}$ fumigation were also important influencing factors for the reduced soil $\mathrm{P}$ availability, which highlighted the fact that microbial mechanisms, especially P solubilizing microbes, need to be studied further to understand the variations in ginger yield and soil $\mathrm{P}$ availability after long-term repeated CP fumigation.

Supplementary Information The online version contains supplementary material available at https://doi.org/10.1007/s11368-022-03135-w.

Acknowledgements We want to thank local farmers and workers who kindly supported to finish the field observation. Robin Palmer is also highly appreciated for language editing.

Author contribution Yan Wang: conceptualization, methodology, formal analysis, investigation, data curation, writing —original draft, visualization. Xiaomei Yang: writing — review and editing, supervision, funding acquisition. Minggang $\mathrm{Xu}$ : conceptualization, resources, writing - review and editing, supervision, project administration, funding acquisition. Violette Geissen: conceptualization, writing review and editing, supervision, project administration.

Funding This research was supported by National Natural Science Foundation of China (41877072) and National R and D key program of China (grant no: 2016YFE011270).

Availability of data and material Data available on reasonable request from the corresponding author.

\section{Declarations}

Ethics approval Not applicable.

Consent to participate Not applicable.

Consent for publication All of the authors have read and approved the paper and it has not been published previously nor is it being considered by any other peer-reviewed journal.

Conflict of interest The authors declare no competing interests.

Open Access This article is licensed under a Creative Commons Attribution 4.0 International License, which permits use, sharing, adaptation, distribution and reproduction in any medium or format, as long as you give appropriate credit to the original author(s) and the source, provide a link to the Creative Commons licence, and indicate if changes were made. The images or other third party material in this article are included in the article's Creative Commons licence, unless indicated otherwise in a credit line to the material. If material is not included in the article's Creative Commons licence and your intended use is not permitted by statutory regulation or exceeds the permitted use, you will need to obtain permission directly from the copyright holder. To view a copy of this licence, visit http://creativecommons.org/licenses/by/4.0/.

\section{References}

Acosta-Martínez V, Tabatabai MA (2015) Phosphorus cycle enzymes methods. Soil Enzymol 79415:161-183. https://doi.org/10.2136/ sssabookser9.c8

Ashworth DJ, Yates SR (2019) Effect of application rate on chloropicrin half-life and simulated emissions across a range of soil conditions. Sci Total Environ 682:457-463. https://doi.org/10.1016/j. scitotenv.2019.05.203

Ashworth DJ, Yates SR, Stanghellini M, van Wesenbeeck IJ (2018) Application rate affects the degradation rate and hence emissions of chloropicrin in soil. Sci Total Environ 622-623:764-769. https://doi.org/10.1016/j.scitotenv.2017.12.060

Costa MG, Gama-Rodrigues AC, Gonçalves JLDM, Gama-Rodrigues EF, Sales MVDS, Aleixo S (2016) Labile and non-labile fractions of phosphorus and its transformations in soil under Eucalyptus plantations, Brazil. Forests 7:1-15. https://doi.org/10.3390/f7010015

Dangi SR, Gerik JS, Tirado-Corbalá R, Ajwa H (2015) Soil microbial community structure and target organisms under different fumigation treatments. Appl Environ Soil Sci. https://doi.org/10.1155/ 2015/673264

Dangi SR, Tirado-Corbala R, Cabrera JA, Wang D, Gerik J (2014) Soil biotic and abiotic responses to dimethyl disulfide spot drip fumigation in established grape vines. Soil Sci Soc Am J 78:520-530. https://doi.org/10.2136/sssaj2013.08.0324

Dangi SR, Tirado-Corbalá R, Gerik J, Hanson BD (2017) Effect of long-term continuous fumigation on soil microbial communities. Agronomy 7:1-15. https://doi.org/10.3390/agronomy7020037

Dick WA, Cheng L, Wang P (2000) Soil acid and alkaline phosphatase activity as $\mathrm{pH}$ adjustment indicators. Soil Biol Biochem 32:19151919. https://doi.org/10.1016/S0038-0717(00)00166-8

Fan Y, Zhong X, Lin F, Liu C, Yang L, Wang M, Chen G, Chen Y, Yang Y (2019) Responses of soil phosphorus fractions after nitrogen addition in a subtropical forest ecosystem: insights from decreased $\mathrm{Fe}$ and $\mathrm{Al}$ oxides and increased plant roots. Geoderma 337:246-255. https://doi.org/10.1016/j.geoderma.2018.09.028

Fang W, Yan D, Wang X, Huang B, Wang X, Liu J, Liu X, Li Y, Ouyang C, Wang Q, Cao A (2018) Responses of nitrogen-cycling microorganisms to dazomet fumigation. Front Microbiol 9:1-13. https:// doi.org/10.3389/fmicb.2018.02529

Fraser TD, Lynch DH, Gaiero J, Khosla K, Dunfield KE (2017) Quantification of bacterial non-specific acid (phoC) and alkaline (phoD) phosphatase genes in bulk and rhizosphere soil from organically managed soybean fields. Appl Soil Ecol 111:48-56. https://doi. org/10.1016/j.apsoil.2016.11.013

Hedley MJ, Stewart JWB, Chauhan BS (1982) Changes in inorganic and organic soil phosphorus fractions induced by cultivation practices and by laboratory incubations. Soil Sci Soc Am J 46:970976. https://doi.org/10.2136/sssaj1982.03615995004600050017x

Hu B, Jia Y, Zhao ZH, Li FM, Siddique KHM (2012) Soil P availability, inorganic $\mathrm{P}$ fractions and yield effect in a calcareous soil with plastic-film-mulched spring wheat. F Crop Res 137:221-229. https://doi.org/10.1016/j.fcr.2012.08.014

Huang B, Yan D, Ouyang C, Zhang D, Zhu J, Liu J, Li Y, Wang Q, Han Q, Cao A (2020a) Chloropicrin fumigation alters the soil phosphorus and the composition of the encoding alkaline phosphatase PhoD gene microbial community. Sci Total Environ 711:135080. https://doi.org/10.1016/j.scitotenv.2019.135080

Huang B, Yan D, Wang Q, Fang W, Song Z, Cheng H, Li Y, Ouyang C, Han Q, Jin X, Cao A (2020b) Effects of dazomet fumigation on 
soil phosphorus and the composition of phoD-harboring microbial communities. J Agric Food Chem 68:5049-5058. https://doi.org/ 10.1021/acs.jafc. $9 \mathrm{~b} 08033$

Jiang Y, Liao Q, Li H, Zou Y (2018) Ginger: response to pathogenrelated diseases. Physiol Mol Plant Pathol 102:88-94. https://doi. org/10.1016/j.pmpp.2017.12.003

Koch M, Kruse J, Eichler-Löbermann B, Zimmer D, Willbold S, Leinweber P, Siebers N (2018) Phosphorus stocks and speciation in soil profiles of a long-term fertilizer experiment: evidence from sequential fractionation, $\mathrm{P}$ K-edge XANES, and 31P NMR spectroscopy. Geoderma 316:115-126. https://doi.org/10.1016/j. geoderma.2017.12.003

Lemming C, Oberson A, Magid J, Bruun S, Scheutz C, Frossard E, Jensen LS (2019) Residual phosphorus availability after longterm soil application of organic waste. Agric Ecosyst Environ 270-271:65-75. https://doi.org/10.1016/j.agee.2018.10.009

Li J, Huang B, Wang Q, Li Y, Fang W, Han D, Yan D, Guo M, Cao A (2017a) Effects of fumigation with metam-sodium on soil microbial biomass, respiration, nitrogen transformation, bacterial community diversity and genes encoding key enzymes involved in nitrogen cycling. Sci Total Environ 598:1027-1036. https://doi. org/10.1016/j.scitotenv.2017.02.058

Li J, Huang B, Wang Q, Li Y, Fang W, Yan D, Guo M, Cao A (2017b) Effect of fumigation with chloropicrin on soil bacterial communities and genes encoding key enzymes involved in nitrogen cycling. Environ Pollut 227:534-542. https://doi.org/10.1016/j. envpol.2017.03.076

Liu X, Cheng X, Wang H, Wang K, Qiao K (2015) Effect of fumigation with 1,3-dichloropropene on soil bacterial communities. Chemosphere 139:379-385. https://doi.org/10.1016/j.chemosphere.2015. 07.034

Mansfield J, Genin S, Magori S, Citovsky V, Sriariyanum M, Ronald P, Dow M, Verdier V, Beer SV, Machado MA, Toth I, Salmond G, Foster GD (2012) Top 10 plant pathogenic bacteria in molecular plant pathology. Mol Plant Pathol 13:614-629. https://doi.org/10. 1111/j.1364-3703.2012.00804.x

Milić S, Ninkov J, Zeremski T, Latković D, Šeremešić S, Radovanović V, Žarković B (2019) Soil fertility and phosphorus fractions in a calcareous chernozem after a long-term field experiment. Geoderma 339:9-19. https://doi.org/10.1016/j.geoderma.2018.12.017

Motavalli PP, Miles RJ (2002) Soil phosphorus fractions after 111 years of animal manure and fertilizer applications. Biol Fertil Soils 36:35-42. https://doi.org/10.1007/s00374-002-0500-6

Neilson JAD, Robertson CJ, Snowdon EW, Yevtushenko DP (2020) Impact of fumigation on soil microbial communities under potato cultivation in Southern Alberta. Am J Potato Res 97:115-126. https://doi.org/10.1007/s12230-019-09761-4

Olsen SR, Cole CV, Watandbe F, Dean L (1954) Estimation of available phosphorus in soil by extraction with sodium bicarbonate. $\mathrm{J}$ Chem Inf Model

Pecina J, Minuto A, Bruzzone C, Romić M (2016) Effects of chloropicrin soil fumigation on pathogenic and beneficial soil microbial populations in tomato production in EU. Acta Hortic 1142:141146. https://doi.org/10.17660/ActaHortic.2016.1142.22

Qiao K, Wang HY, Shi XB, Ji XX, Wang KY (2010) Effects of 1, 3-dichloropropene on nematode, weed seed viability and soilborne pathogen. Crop Prot 29:1305-1310. https://doi.org/10. 1016/j.cropro.2010.07.014

Qin R, Gao S, Ajwa H, Hanson BD (2016) Effect of application rate on fumigant degradation in five agricultural soils. Sci Total Environ 541:528-534. https://doi.org/10.1016/j.scitotenv.2015.09.062

Richardson AE, Hocking PJ, Simpson RJ, George TS (2009) Plant mechanisms to optimise access to soil phosphorus. Crop Pasture Sci 60:124-143. https://doi.org/10.1071/CP07125

Rokunuzzaman M, Hayakawa A, Yamane S, Tanaka S, Ohnishi K (2016) Effect of soil disinfection with chemical and biological methods on bacterial communities. Egypt J Basic Appl Sci 3:141148. https://doi.org/10.1016/j.ejbas.2016.01.003

Rosa RH, Ribeiro Fernandes M, De Pádua Melo ES, Granja Arakaki D, De Lima NV, Santos Leite LC, Espindola PR, De Souza ID, Nascimento Do, Aragão V, Saldanha Tschinkel PF, La Flor Ziegler Sanches F, Aragão Do Nascimento V (2020) Determination of macro- and microelements in the inflorescences of banana tree using ICP OES: evaluation of the daily recommendations of intake for humans. Sci World J. https://doi.org/10.1155/2020/8383612

Schaller J, Faucherre S, Joss H, Obst M, Goeckede M, Planer-Friedrich B, Peiffer S, Gilfedder B, Elberling B (2019) Silicon increases the phosphorus availability of Arctic soils. Sci Rep 9:1-11. https:// doi.org/10.1038/s41598-018-37104-6

Smith SE, Smith FA (2011) Roles of arbuscular mycorrhizas in plant nutrition and growth: new paradigms from cellular to ecosystem scales. Annu Rev Plant Biol 62:227-250. https://doi.org/10.1146/ annurev-arplant-042110-103846

Spohn M, Kuzyakov Y (2013) Phosphorus mineralization can be driven by microbial need for carbon. Soil Biol Biochem 61:69-75. https://doi.org/10.1016/j.soilbio.2013.02.013

Sun X, Li M, Wang G, Drosos M, Liu F, Hu Z (2019) Response of phosphorus fractions to land-use change followed by long-term fertilization in a sub-alpine humid soil of Qinghai-Tibet plateau. J Soils Sediments 19:1109-1119. https://doi.org/10.1007/ s11368-018-2132-y

Sun Z, Zhang C, Li G, Lin Q, Zhao X (2018) Does soil amendment alter reactive soil $\mathrm{N}$ dynamics following chloropicrin fumigation? Chemosphere 212:563-571. https://doi.org/10.1016/j. chemosphere.2018.08.084

Tabatabai MA, Bremner JM (1969) Use of p-nitrophenyl phosphate for assay of soil phosphatase activity. Soil Biol Biochem 1:301-307. https://doi.org/10.1016/0038-0717(69)90012-1

Tiessen H (2006) Chapter 25 Characterization of available p by sequential extraction. Methods 293-306

Wan W, Li X, Han S, Wang L, Luo X, Chen W, Huang Q (2020) Soil aggregate fractionation and phosphorus fraction driven by longterm fertilization regimes affect the abundance and composition of P-cycling-related bacteria. Soil Tillage Res. https://doi.org/10. 1016/j.still.2019.104475

Wang Y, Marschner P, Zhang F (2012) Phosphorus pools and other soil properties in the rhizosphere of wheat and legumes growing in three soils in monoculture or as a mixture of wheat and legume. Plant Soil 354:283-298. https://doi.org/10.1007/ s11104-011-1065-7

Weihrauch C, Opp C (2018) Ecologically relevant phosphorus pools in soils and their dynamics: the story so far. Geoderma 325:183-194. https://doi.org/10.1016/j.geoderma.2018.02.047

Yan D, Wang Q, Li Y, Ouyang C, Guo M, Cao A (2017) Analysis of the inhibitory effects of chloropicrin fumigation on nitrification in various soil types. Chemosphere 175:459-464. https://doi.org/ 10.1016/j.chemosphere.2017.02.075

Yao S, Merwin IA, Abawi GS, Thies JE (2006) Soil fumigation and compost amendment alter soil microbial community composition but do not improve tree growth or yield in an apple replant site. Soil Biol Biochem 38:587-599. https://doi.org/10.1016/j.soilbio.2005.06.026

Zhang D, Ji X, Meng Z, Qi W, Qiao K (2019) Effects of fumigation with 1,3-dichloropropene on soil enzyme activities and microbial communities in continuous-cropping soil. Ecotoxicol Environ Saf 169:730-736. https://doi.org/10.1016/j.ecoenv.2018.11.071

Zhang D, Yan D, Cheng H, Fang W, Huang B, Wang X, Wang X, Yan Y, Ouyang C, Li Y, Wang Q, Cao A (2020) Effects of multiyear biofumigation on soil bacterial and fungal communities and strawberry yield. Environ Pollut 256:113415. https://doi.org/10. 1016/j.envpol.2019.113415

Zhang N, Pan R, Shen Y, Yuan J, Wang L, Luo X, Raza W, Ling N, Huang Q, Shen Q (2017a) Development of a novel bio-organic 
fertilizer for plant growth promotion and suppression of rhizome rot in ginger. Biol Control 114:97-105. https://doi.org/10.1016/j. biocontrol.2017.08.001

Zhang S, Liu X, Jiang Q, Shen G, Ding W (2017b) Legacy effects of continuous chloropicrin-fumigation for 3-years on soil microbial community composition and metabolic activity. AMB Express 7:1-11. https://doi.org/10.1186/s13568-017-0475-1

Zhang W, Zhang Y, An Y, Chen X (2021) Phosphorus fractionation related to environmental risks resulting from intensive vegetable cropping and fertilization in a subtropical region. Environ Pollut 269:116098. https://doi.org/10.1016/j.envpol.2020.116098
Zhao F, Zhang Y, Dijkstra FA, Li Z, Zhang Y, Zhang T, Lu Y, Shi J, Yang L (2019) Effects of amendments on phosphorous status in soils with different phosphorous levels. Catena 172:97-103. https://doi.org/10.1016/j.catena.2018.08.016

Zhou X, Xu M, Wang B, Cai Z, Colinet G (2018) Changes of soil phosphorus fractionation according to $\mathrm{pH}$ in red soils of China: an incubation experiment. Commun Soil Sci Plant Anal 49:791-802. https://doi.org/10.1080/00103624.2018.1435676

Publisher's Note Springer Nature remains neutral with regard to jurisdictional claims in published maps and institutional affiliations. 